\title{
Purifikasi Lipase Aspergillus niger M1407 Indigenus Menggunakan Kromatografi Pertukaran Ion
}

\author{
Purification of Aspergillus niger M1407 Indigenous Lipase Using Ion Exchange \\ Chromatography
}

\author{
Mellissa Erlyn Stephanie Ledo ${ }^{1}{ }^{*}$, Hartini Realista Lidya Solle ${ }^{1}$, Merpiseldin Nitsae ${ }^{1}$

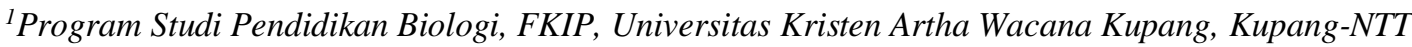 \\ Email: mellissaerlynsledo@gmail.com *Penulis untuk korespondensi
}

\begin{abstract}
Lipase can be used as biocatalyst in biodiesel sinthesis. One of the plants has potential as biocatalyst that is kesambi tree (Schleichera oleosa) which has been identified and cultivated are. The population of kesambi trees at East Nusa Tenggara was high but it has not optimally utilized. Schleichera seeds were known to have high fatty acid content as miristic acid, palmitic acid, stearic acid, arachidic acid oleat acid and linoleic acid. Aspergillus niger M1407 was indigenous lipolitic fungi that was isolated from Schleichera seeds. The aim of this study were 1) to optain purified lipase $A$. niger M1407 by purification process using ion exchange chromatography and 2) to getting a profile of crude lipase $A$. niger M1407. The procedure of this study consisted of four stages 1) sinthesizing of lipase A. niger M1407 by Solid State Fermentation using Schleihera seeds flour as medium fermentation; 2) testing lipase $A$. niger M1407 for pH profile 3) purifying lipase $A$. niger M1407 using cation-exchange choromatography; 4) testing the activity of parsial purified lipase $A$. niger M1407 activity test. The results showed that crude lipase $A$. niger M1407 had optimal pH at 8 with activity 118,52 $\mathrm{U} / \mathrm{mL}$ at room temperature. lipase A. niger M1407 activity after the purification process using cation exchange chromatography was 71,11 U/mL. Therefore, the optimization of lipase $A$. niger M1407 purification process and characterization was necessary to improve biodiesel production by using Scheleichera seeds.
\end{abstract}

Keywords: A. niger M1407 lipase, lipase purification, Kesambi (Schleichera oleosa), East Nusa Tenggara.

Abstrak

Lipase digunakan sebagai biokatalis dalam proses sintesis biodiesel. Salah satu tumbuhan yang memiliki potensi biokatalis telah diidentifikasi dan dibudidayakan yaitu pohon kesambi (Schleichera oleosa) yang populasinya cukup tinggi di Nusa Tenggara Timur dan belum dimanfaatkan secara optimal. Biji kesambi (Schleichera seeds) diketahui memiliki kandungan asam lemak yang cukup tinggi seperti asam miristat, asam palmitat, asam stearate, asam arakidat, asam oleat dan asam linoleat. Isolat Aspergillus niger M1407 adalah isolat fungi lipolitik indigenus yang diisolasi dari biji kesambi. Penelitan ini bertujuan mendapatkan lipase A. niger M1407 yang murni melalui proses purifikasi menggunakan kromatografi pertukaran ion dan mendapatkan profil pH lipase $A$. niger M1407. Tahapan penelitian ini adalah 1) Tahap produksi lipase melalui Solid State Fermentation menggunakan medium tepung biji kesambi; 2) Tahap purifikasi lipase menggunakan cation exchange ; 3) Tahap uji profil pH Lipase $A$. niger M1407; dan 4) Uji aktivitas lipase parsial purifikasi. Hasilnya menunjukkan aktivitas ekstrak kasar lipase $A$. niger M1407 memiliki pH optimal pada pH= 8 dengan aktivitas sebesar 118,52 U/mL pada suhu kamar. Aktivitas lipase $A$. niger M1407 yang telah mengalami purifikasi menggunakan metode kromatografi pertukaran kation (cation exchange chromatography) adalah 71,11 U/mL. Dengan demikian, optimasi purifikasi lipase A. niger M1407 dan karakterisasinya perlu dilakukan dalam upaya pengembangan produksi biodiesel dengan pemanfaatan biji kesambi.

Kata Kunci: Lipase A. niger M1407, Purifikasi lipase, Kesambi (Schleichera oleosa), Nusa Tenggara Timur.

Diterima: 29 Agustus 2017, disetujui: 30 September 2017 


\section{Pendahuluan}

Biodiesel merupakan salah satu energi alternatif pengganti bahan bakar fosil yang sedang dieksplorasi saat ini untuk mengatasi permasalahan krisis global bahan bakar fosil yang terjadi di Indonesia. Diterbitkannya Peraturan Presiden No. 5 Tahun 2006 tentang kebijakan Energi Nasional untuk mengembangkan sumber energi alternatif sebagai bahan bakar pengganti minyak merupakan bentuk pengharapan dari pemerintah terhadap ketergantungan terhadap bahan bakar fosil sehingga akan berkurang dari 52\% menjadi $20 \%$. Selain itu, pemerintah serius untuk mengembangkan bahan bakar nabati dengan menerbitkan Inpres No. 1 Tahun 2006 pada tanggal 25 Juni 2006 tentang penyediaan bahan bakar nabati sebagai sumber bahan bakar. Tumbuhan yang memiliki potensi untuk menjadi bahan baku dalam proses sintesis biodiesel dan enzim lipase telah diidentifikasi dan dibudidayakan, salah satunya adalah pohon kesambi (Schleichera oleosa) yang populasinya cukup tinggi di Nusa Tenggara Timur dan belum dimanfaatkan secara optimal.

Biji kesambi (Schleichera seeds) diketahui memiliki kandungan asam lemak yang cukup tinggi. Beberapa asam lemak pada biji kesambi adalah asam miristat, asam palmitat, asam stearate, asam arakidat, asam oleat dan asam linoleat. Kandungan asam oleat memiliki persentase tertinggi yaitu berkisar 40-60\%. Sele dan Ledo (2013), telah melakukan isolasi dan identifikasi fungi indigenous lipolitik dari biji kesambi, didapatkan 3 isolat fungi yaitu Aspergillus niger, Aspergillus flavus dan Penicillium sp. Selanjutnya Sabath dkk. (2013) telah menggunakan tepung biji kesambi sebagai substrat untuk produksi ekstraseluler lipase, Ledo dkk. (2016) mendapatkan ekstrak crude lipase melalui Solid State Fermentation (SSF) dengan menggunakan biji kesambi sebagai substrat dari A. niger dan Penicillium sp. dengan aktivitas enzim sebesar $137,5 \mathrm{U} / \mathrm{mL}$ dan 50 $\mathrm{U} / \mathrm{mL}$. Aktivitas crude lipase A.niger yang cukup tinggi memberikan peluang yang cukup besar untuk dapat digunakan sebagai biokatalis dalam produksi biodiesel skala industri. Dengan demikian, perlu dilakukan purifikasi dan karakterisasi lipase A. niger M1407 parsial purifikasi untuk meningkatkan aktivitasnya serta mendapatkan profil lipase A. niger M1407 yang diekstraksi dari tepung biji kesambi.

Metode purifikasi yang digunakan yaitu kromatografi ion exchange menggunakan matrix penukar kation Amberlite IRA-400. Purifikasi menggunakan kromatografi ion exchange memiliki beberapa kelebihan antara lain kecepatan pemisahan/pendeteksian, bisa dilakukan pemisahan menggunakan kolom kation atau anion yang sesuai dengan sampel, kolom pemisah bisa bertahan pada perubahan yang terjadi pada sampel, tidak akan mempengaruhi kestabilan material penyusun kolom. Penggunaan kromatografi ion exchange diharapkan dapat memisahkan molekul protein enzim dari molekul lainnya sehingga meningkatkan kemurniannya. Lipase yang telah dimurnikan kemudian diuji aktivitas lipolitiknya. Hasil penelitian ini, memberikan informasi tentang sumber lipase yang baru yaitu biji kesambi dan aktivitas lipase A. niger M1407 yang cukup tinggi sehingga memiliki potensi untuk pemanfaatan yang lebih luas dalam dunia industri.

\section{Metode Penelitian}

\section{Bahan dan Alat}

Biji kesambi, olive oil, n-Heksana p.a, buffer fosfat, $\mathrm{NaCl}$, resin (cation Exchanger Amberlite IR $400 \mathrm{Cl}$ ), Natrium Hidroksida p.a, Indikator PP, natrium nitrat, etanol p.a, kolom kromatografi (kolom kaca, diameter kolom adalah $1,5 \mathrm{~cm}$ dan panjang $15 \mathrm{~cm}$ ), autoklaf (Hiclave, HVE-50, Hirayama)Shaker (Orbital Shaker, OS-762, OPTIMA), sentrifuge 80-2, tabung ependorf, Erlenmeyer, gelas beker, mikropipet, buret, dan cool box.

\section{Prosedur Produksi Ektrak Kasar Lipase Ekstraseluler Menggunakan Solid State Fermentation (SSF)}

Sebanyak $50 \mathrm{~g}$ bungkil biji kesambi yang telah di-defatting dalam erlenmeyer $1000 \mathrm{~mL}$ ditambahkan dengan olive oil $2 \%(\mathrm{v} / \mathrm{w}), \mathrm{NaNO}_{3}$ $1 \%(\mathrm{v} / \mathrm{w})$ dan akuades $50 \%$. Medium diaduk kemudian disterilisasi dengan autoklaf pada suhu $121^{\circ} \mathrm{C}$ selama 60 menit. Medium diinokulasi dengan $10 \mathrm{~mL}$ suspensi spora fungi $\left(10^{7}\right.$ 
spora/mL), lalu diinkubasi pada suhu ruang selama 7 hari. Kemudian sampel dari hasil fermentasi (ekstrak kasar lipase) ditambah dengan $0,1 \mathrm{M}$ buffer fosfat $\mathrm{pH} 8,0 \quad(3 \mathrm{~mL} / \mathrm{g}$ medium). Campuran diaduk menggunakan shaker $100 \mathrm{rpm}$ selama 20 menit pada suhu ruang. Campuran kemudian disaring. Filtrat/supernatan disentrifuge (3000 rpm) suhu $4^{\circ} \mathrm{C}$, selama 20 menit untuk memisahkan padatan. Supernatan yang diperoleh merupakan crude enzim disimpan pada suhu $-16^{\circ} \mathrm{C}$ untuk selanjutnya dilakukan analisis aktivitas esterifikasinya (Modifikasi metode dari Darmasiwi, 2010).

Prosedur Karakterisasi lipase A. niger M1407 pada Berbagai Variasi pH

Sebanyak $1 \mathrm{~g}$ hasil SSF diekstrak dengan buffer $0,1 \mathrm{M}$ buffer phosphat $\mathrm{pH} 6,0 ; 7,0 ; 8,0$; 9,0 . Selanjutnya larutan diuji aktivitas esterifikasinya dengan metode titrasi.

\section{Prosedur Purifikasi Lipase Menggunakan Kromatogafi Pertukaran Ion}

Sebanyak $2 \mathrm{~g}$ resin (cation Exchanger Amberlite IR $400 \mathrm{Cl}$ ) dimasukkan dalam kolom kemudian dicuci dengan $0,1 \mathrm{M}$ buffer phospat $\mathrm{pH}$ 8,0 (sebanyak 3x). Resin dimasukkan ke dalam kolom yang berisi $0,1 \mathrm{M}$ buffer phosphat $\mathrm{pH} 8,0$. Selanjutnya sebanyak $1 \mathrm{~mL}$ sampel crude lipase dimasukkan dalam kolom dan dialirkan ke dalam kolom. Sampel ditampung dalam tabung ependorf. Elusi dilakukan dengan $0,1 \mathrm{M} ; 0,5 \mathrm{M}$; $1 \mathrm{M} \mathrm{NaCl}$ dalam $0,1 \mathrm{M}$ buffer phosphate $\mathrm{pH}$ 6,0 sebanyak $5 \mathrm{ml}$ ke dalam kolom secara gradien. Eluen ditampung dalam tabung ependorf. Eluent yang telah tertampung kemudian di uji protein terlarutnya dan aktivitas esterifikasinya (Modifikasi metode dari Scopes, 1994).

\section{Prosedur Analisis Aktivitas Lipase dengan Metode Titrasi}

Sebanyak $2 \mathrm{~mL}$ asam oleat dimasukkan ke dalam erlenmeyer kemudian ditambahkan $2 \mathrm{~mL}$ enzim crude/parsial purifikasi. Selanjutnya diletakkan pada shaker selama 30 menit, selanjutnya substrat enzim diinaktifkan dengan menggunakan campuran aseton : etanol (1:1) sebanyak $5 \mathrm{~mL}$. Campuran tersebut ditambahkan 5 tetes fenolftalein 1\% sebagai indikator dan dititrasi dengan menggunakan larutan $\mathrm{NaOH}$
0,05 M. Titrasi dihentikan setelah campuran berubah menjadi merah muda. Aktivitas lipase ditentukan dari volume $\mathrm{NaOH}$ untuk titrasi sampel dikurangi volume $\mathrm{NaOH}$ untuk titrasi kontrol. Setiap $1 \mathrm{ml} \mathrm{NaOH} 50 \mathrm{mM}$ setara dengan 100 unit aktivitas lipase. Unit aktivitas enzim dihitung dengan rumus :

$\frac{(\mathrm{V} \mathrm{NaOH} \text { sampel - V NaOH kontrol) }}{\text { volume enzim }}$ X $100 \quad$ (unit/ mL)

(Lestari dkk., 2009)

\section{Hasil dan Pembahasan}

\section{Profil pH Lipase Aspergillus niger M1407}

Ekstrak kasar lipase Aspergillus niger M1407 diekstraksi dari hasil Solid State Fermentation (SSF) biji kesambi melalui proses defatting dan diinokulasi dengan A. niger M1407 indigenus yang diisolasi dari biji kesambi (Schleichera seeds) selama 5 hari. Proses ekstraksi menggunakan larutan buffer fosfat $\mathrm{pH}$ $6,7,8$, dan 9 yang menunjukkan aktivitas yang cukup bervariasi. Tahapan ekstraksi lipase sampai pada penentuan aktivitas berdasarkan variasi $\mathrm{pH}$ yang berbeda dapat dilihat pada Gambar 1.

Menurut Lehninger dkk., (1993), aktivitas lipase mencapai kondisi maksimal pada $\mathrm{pH}$ optimum dalam mengikat substrat dan mengkatalisis reaksi. Perubahan $\mathrm{pH}$ menyebabkan berubahnya muatan lipase atau substrat, selain itu dapat mengubah struktur atau muatan residu fungsional pada sisi pengikatan substrat lipase. Perubahan $\mathrm{pH}$ yang ekstrim dapat mempengaruhi derajat ionisasi asam amino yang bermuatan sehingga menyebabkan putusnya ikatan intra dan intermolekuler yang diikuti dengan berubahnya struktur lipase. Hal ini mengakibatkan terjadinya penurunan efektivitas dan efisiensi enzim dalam mengikat dan mengkatalisis substrat (Farabee, 2001). Aktivitas ekstrak kasar lipase A. niger M1407 pada larutan buffer fosfat dengan variasi $\mathrm{pH} 6,0$; 7, 0; 8,0 dan 9,0 dapat dilihat pada Gambar 2 .

Aktivitas ekstrak kasar lipase $A$. niger M1407 pada pH 6,0 adalah 65,19 U/mL kemudian pada $\mathrm{pH}$ 7,0 mengalami peningkatan sebesar $30 \%$. Aktivitas tertinggi lipase A. niger M1407 terjadi pada pH 8,0 yaitu 118,52 U/mL 
dan mengalami penurunan aktivitas sebesar $30 \%$ pada $\mathrm{pH}$ 9,0. Menurunnya aktivitas lipase terjadi karena perubahan $\mathrm{pH}$ larutan yang menyebabkan ionisasi gugus-gugus fungsionalnya $\left(-\mathrm{OH},-\mathrm{NH}_{2}\right.$, ${ }_{-}^{+} \mathrm{NH}_{3}$, dan $\left.-\mathrm{C}=\mathrm{O}\right)$ menjadi bentuk muatan.

\section{Aktivitas Lipase A. niger M1407 yang Telah Mengalami Proses Purifikasi dengan Metode Cation Exchange Chromatography}

Purifikasi ekstrak kasar lipase A. niger M1407 menggunakan kromatografi cation exchange chromatography dilakukan dengan menggunakan matriks ion exchanger Amberlite IR-120 (strongly acidic cation exchanger $\mathrm{Na}^{+}$ form), sehingga matriks ini bermuatan negatif. Proses equilibrasi dengan $\mathrm{pH}$ adsorpsi akan menyebabkan matriks bermuatan negatif mengikat ion bermuatan positif. Lipase (bermuatan positif) akan terikat pada matriks dan protein pengotor bermuatan negatif akan lolos (unbound).

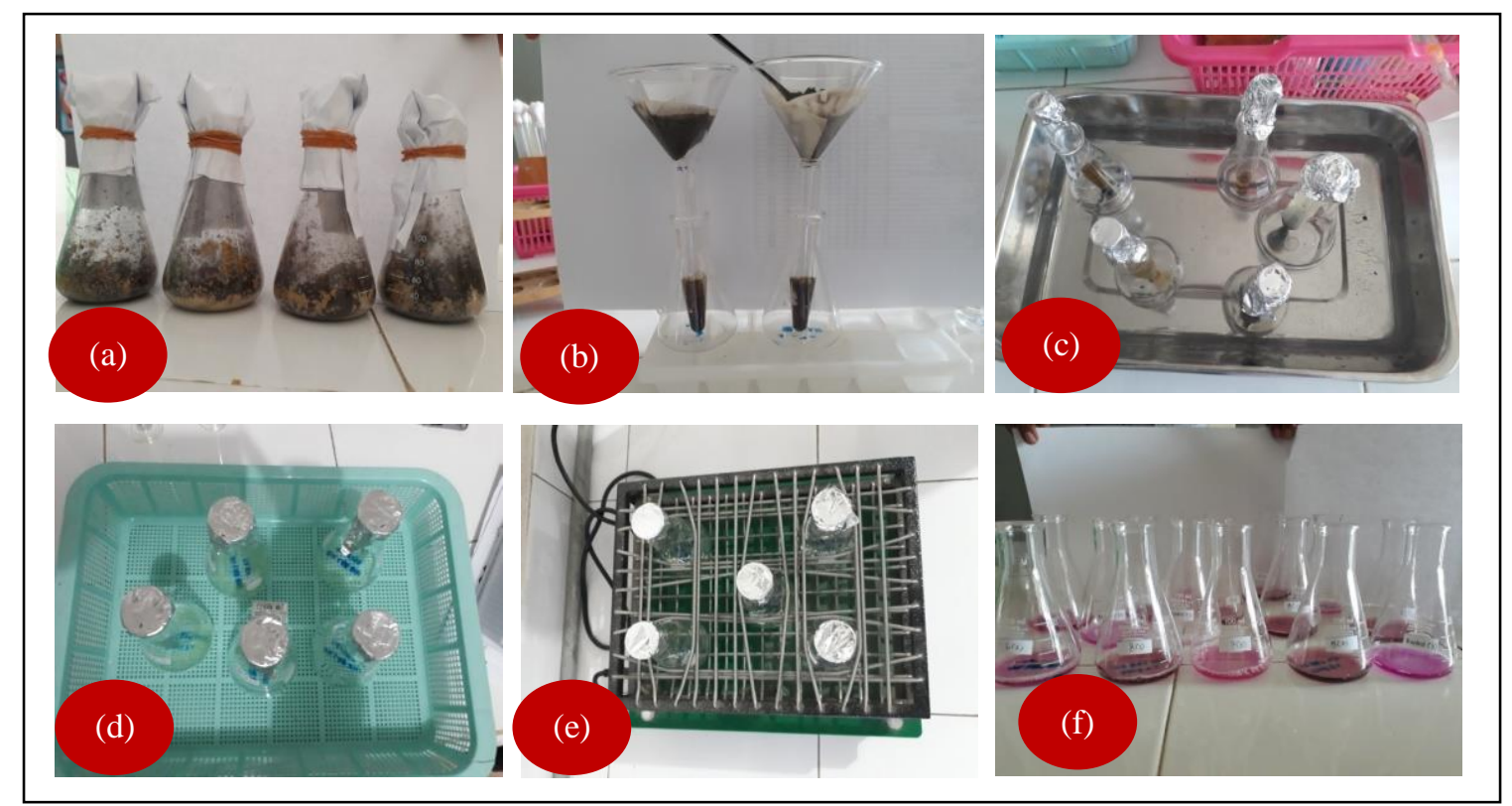

Gambar 1. Tahapan ekstraksi lipase sampai penentuan aktivitas enzim: (a). Fermentasi lipase menggunakan A. niger M1407; (b). Ekstraksi Crude lipase; (c). Crude Lipase; (d). Crude Lipase + asam oleat; (e). Crude Lipase + asam oleat digojog menggunakan shaker dengan kecepatan $150 \mathrm{rpm}, \pm 30$ menit; dan (f). Hasil akhir titrasi untuk penentuan aktivitas enzim (crude Lipase + asam oleat + etanol + aseton + indikator pp dititrasi menggunakan $\mathrm{NaOH} 0,1$ M); (Sumber: Ledo dkk, 2016).

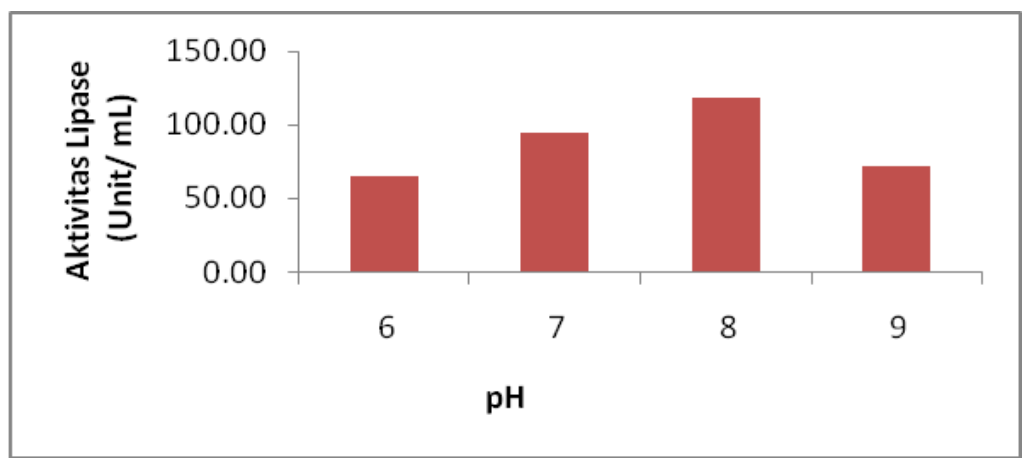

Gambar 2. Diagram aktivitas ekstrak kasar lipase A. niger M1407 pada pH yang berbeda. 
Sisi aktif lipase mempunyai 3 asam amino yang berperan dalam reaksi katalitiknya yaitu asam aspartat, histidin dan serin. Sisi aktif lipase berada pada asam amino serin yaitu gugus hidroksil $(-\mathrm{OH})$ dari serin akan berikatan kovalen dengan substratnya (Pouderoyen dkk., 2001). Dengan demikian muatan yang dimiliki asam amino penyusun lipase bervariasi yaitu negatif, positif, tidak bermuatan, serta bersifat polar. Proses untuk mengubah muatan yang dimiliki oleh lipase A. niger M1407 perlu dilakukan sehingga dapat berikatan dengan matriks saat purifikasi. Berdasarkan penelitian yang telah dilakukan Nurikasari (2011), titik isoelektrik (pI) Aspergillus niger $65 \mathrm{I} 6$ adalah pada $\mathrm{pH} 7,0$. Hasil yang didapat sesuai dengan penelitian Hidayat dkk. (2015), tentang karakterisasi lipase A. niger $65 \mathrm{I} 6$ melalui fermentasi menggunakan medium bungkil jarak (Jatropha seeds) menyatakan bahwa lipase adalah enzim yang spesifik untuk substrat asam lemak rantai panjang, bersifat stabil pada pelarut polar, memiliki berat molekul $19 \mathrm{kDa}$, dan tergolong dalam lipase alkali (basa). Dengan demikian, muatan lipase A. niger M1407 adalah positif jika dikondisikan pada $\mathrm{pH}$ basa, sehingga agar lipase A. niger M1407 dapat berikatan dengan matriks cation exchange maka $\mathrm{pH}$ larutan buffer yang digunakan harus bersifat asam (di bawah titik isoelektrik). Dalam penelitian ini $\mathrm{pH}$ larutan buffer fosfat yang digunakan adalah pH 6 dengan konsentrasi 0,1 M. Proses purifikasi dilakukan dengan menggunakan kolom kromatografi dengan ukuran diameter kolom adalah $1,5 \mathrm{~cm}$ dan panjang $15 \mathrm{~cm}$. Hal ini menyebabkan tahapan elusidasi akan berjalan lambat karena matriks yang digunakan semakin banyak. Sebaliknya jika diameter dan panjang kolom semakin kecil maka jumlah matriks yang digunakan sedikit menyebabkan tahapan elusidasi berjalan lebih cepat. Pada penelitian ini jumlah matriks Amberlite IR-120 digunakan sebanyak 5 g yang menempati kolom sepanjang 7,3 $\mathrm{cm}$ dari panjang $15 \mathrm{~cm}$ (Gambar 3a).

Hasil purifikasi lipase A. niger M1407 dengan metode cation exchange chromatography menunjukkan bahwa lipase yang terikat pada matriks dan dielusi menggunakan larutan $\mathrm{NaCl}$ dengan konsentrasi
0,1 M ; 0,5 M; dan $1 \mathrm{M}$ (elusi bergradien artinya tahapan elusidasi dimulai dari konsentrasi yang kecil ke konsentrasi besar) memiliki aktivitas yang lebih rendah dari pada crude lipase $A$. niger M1407. Aktivitas lipase A. niger M1407 yang telah dipurifikasi dengan cation exchange chromatography didapatkan dengan menguji aktivitas lipase A. niger M1407 yang terdapat pada fraksi elusi menggunakan larutan $\mathrm{NaCl}$ dengan konsentrasi $0,1 \mathrm{M} ; 0,5 \mathrm{M}$ dan $1 \mathrm{M}$. Uji aktivitas lipase parsial purifikasi dilakukan dengan metode titrasi menggunakan larutan $\mathrm{NaOH}$, hasil uji aktivitas lipase A. niger M1407 setelah elusidasi terlihat pada Gambar 3b.

Untuk setiap tahapan elusi yang menghasilkan 22 fraksi dibutuhkan waktu crude lipase melewati kolom selama 10 menit dan waktu retensi per tetes adalah 20 detik. Hal ini disebabkan karena diameter dan panjang kolom yang cukup besar menyebabkan tahapan elusi menjadi lambat. Dengan demikian, pola elusi yang disajikan dalam Gambar 3a menunjukkan aktivitas lipase parsial purifikasi pada setiap fraksi yang dielusi menggunakan $\mathrm{NaCl}$ dengan konsentrasi bertingkat.

Aktivitas lipase A. niger M1407 parsial purifikasi, pada tahap elusi menggunakan larutan $\mathrm{NaCl} 0,1 \mathrm{M}$ adalah $71,11 \mathrm{U} / \mathrm{mL}$, sedangkan pada tahap elusi dengan larutan $\mathrm{NaCl} 0,5 \mathrm{M}$, aktivitasnya adalah 35,56 U/mL (lihat Gambar 3b). Jika dibandingkan dengan crude lipase $A$. niger M1407 maka aktivitas lipase parsial purifikasi memiliki aktivitas 50\% lebih rendah daripada aktivitas crude lipase, namun diduga aktivitas spesifik lipase A. niger M1407 parsial purifikasi lebih tinggi daripada aktivitas spesifik crude lipase. Hal ini disebabkan oleh total protein yang dimiliki oleh crude lipase lebih besar daripada total protein lipase A. niger M1407 parsial purifikasi. Pernyataan ini didukung oleh hasil penelitian Nurikasari (2011) yang menunjukkan bahwa hasil lipase Aspergillus niger 6516 menggunakan kromatografi ion exchange meningkatkan kemurnian lipase menjadi 12,12 kali, dengan yield sebesar $86,11 \%$. Total protein pada ekstrak kasar lipase Aspergillus niger 6516 adalah 5,57 mg sedangkan pada lipase hasil adalah $0,57 \mathrm{mg}$ sehingga aktivitas spesifik lipase hasil lebih besar daripada ekstrak kasar lipase tersebut. 


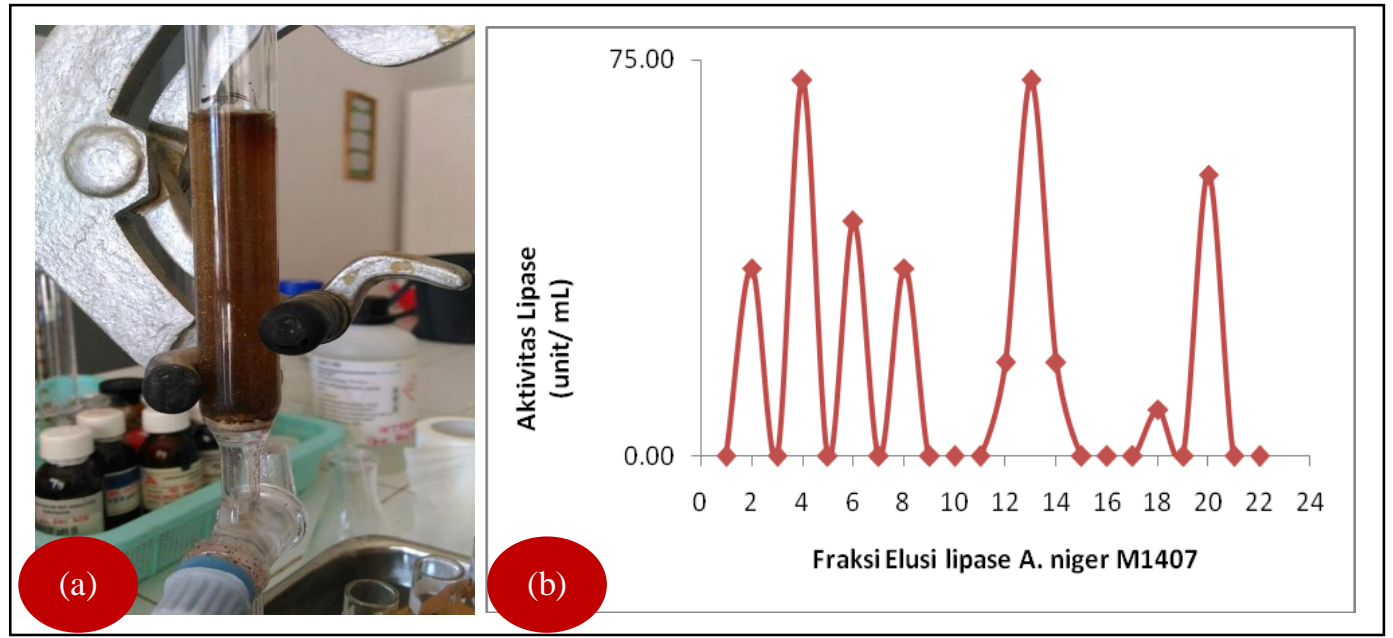

Gambar 3. (a). Purifikasi ekstrak kasar lipase A. niger M1407 menggunakan cation exchange chromatography (b). Aktivitas lipase A. niger M1407 parsial purifikasi (fraksi elusi)

\section{Simpulan}

Penentuan aktivitas ekstrak kasar lipase $A$. niger M1407 telah dilakukan pada kondisi $\mathrm{pH}$ optimum pada suhu kamar. Aktivitas lipase $A$. niger M1407 parsial purifikasi menggunakan metode cation exchange chromatography. Dengan demikian profil crude lipase A. niger M1407 perlu dilengkapi dengan karakterisasi berat molekulnya.

\section{Ucapan Terima Kasih}

Terima kasih kepada Fakultas Keguruan dan Ilmu Pendidikan (FKIP), Universitas Kristen Artha Wacana kupang yang telah membantu pendanaan penelitian ini.

\section{Daftar Pustaka}

Darmasiwi, S. 2010. Screening Isolat Lipolitik Indigenus dan Karakterisasi Lipase Yang Dihasilkan Pada Solid-State Fermentation. Thesis. Program Studi Bioteknologi. Universitas Gadjah Mada, Yogyakarta.

Farabee, M.J. 2001. Enzyme: Organic catalyst. W.HFreeman \& Co. USA.
Hidayat, C., Darmasiwi, S., Nurikasari, M., Cahyanto, M.N. 2015. Characterization of Aspergillus Niger 65 i6 lipase from solid-state fermentation using Jatropha seed cake medium. Indonesian Journal of Biotechnology 20 (2): 108 - 116

Ledo, M.E.S., Dima, Y.R. dan Nope, J.V.V. 2016. Aktivitas lipolitik Aspergillus niger dan Penicillium sp indigenous yang diisolasi dari biji kesambi (Schleichera oleosa). Prosiding Seminar nasional SAINS dan TEKNIK UNDANA 3. Kupang.

Lehninger, A., Nelson, D. dan Cox, M.M. 1993, Principles of Biochemistry $2^{\text {nd }}$. W.H. Freeman and Company, New York.

Lestari, P., Handayani, S.N. dan Oedjijono. 2009. Sifat-sifat Biokimiawi Ekstrak Kasar Lipase Ekstraseluler Dari Bakteri Azospirillum sp. JG3. Program Studi Kimia, Jurusan MIPA Fakultas Sains dan Teknik UNSOED, Purwokerto Fakultas Biologi UNSOED. Purwokerto.

Nurikasari, M. 2011. Optimasi Kondisi, Karakterisasi Dan Kinetika Esterifikasi Lipase Aspergillus Niger 6516 Dari Solid State Fermentation Pada Medium Bungkil Jarak. Thesis, Program Studi Bioteknologi Program Pascasarjana Universitas Gadjah Mada, Yogyakarta.

Peraturan Presiden Republik Indonesia Nomor 5 Tahun 2006 Tentang Kebijakan Energi Nasional

Pouderoyen, V.G., Eggert, T., Jaeger, K.E. dan Dijkstra, B.W.2001. The Crystal Structure of Bacillus subtilis Lipase: A Minimal $\alpha / \beta$ Hydrolase Fold Enzyme. Journal of J.M.B. 309: 215-226. 
Mellissa Erlyn Stephanie Ledo dkk.

Sabath, Y.S.A. 2013. Produksi Lipase Oleh Aspergillus niger Dengan Pemanfaatan Biji Kesambi (Schleichera oleosa) Sebagai Medium Melalui Solid State Fermentation. Skripsi, Program Studi Biologi, Universitas Kristen Artha Wacana, Kupang.

Scopes, R.K. 1994. Protein Purification, Principles and Practice. Third edition. Springer-Verlag. New York.
Sele, Y. dan Ledo, M. 2013. Isolasi dan identifikasi fungi lipolitik dari biji kesambi (Schleichera oleosa). Jurnal Biotropika Sains. Universitas Nusa Cendana, Kupang. 